\title{
A cohabitation challenge to compare the efficacies of vaccines for bacterial kidney disease (BKD) in chinook salmon Oncorhynchus tshawytscha
}

\author{
Stewart Alcorn ${ }^{1, *}$, Anthony L. Murray ${ }^{2}$, Ronald J. Pascho ${ }^{2}$, Jed Varney ${ }^{3}$ \\ ${ }^{1}$ School of Aquatic and Fishery Sciences, University of Washington, 1122 Boat Street, Seattle, Washington 98195, USA \\ ${ }^{2}$ Western Fisheries Research Center, US Geological Survey, 6505 NE 65th Street, Seattle, Washington 98115, USA \\ ${ }^{3}$ Washington Department of Fish and Wildlife, Kendall Creek Hatchery, 6263 Mt. Baker Highway, Deming, \\ Washington 98244, USA
}

\begin{abstract}
The relative efficacies of 1 commercial and 5 experimental vaccines for bacterial kidney disease (BKD) were compared through a cohabitation waterborne challenge. Groups of juvenile chinook salmon Oncorhynchus tshawytscha were vaccinated with one of the following: (1) killed Renibacterium salmoninarum ATCC 33209 (Rs 33209) cells; (2) killed Rs 33209 cells which had been heated to $37^{\circ} \mathrm{C}$ for $48 \mathrm{~h}$, a process that destroys the p57 protein; (3) killed $R$. salmoninarum MT239 (Rs MT239) cells; (4) heated Rs MT239 cells; (5) a recombinant version of the p57 protein (r-p57) emulsified in Freund's incomplete adjuvant (FIA); (6) the commercial BKD vaccine Renogen; (7) phosphatebuffered saline (PBS) emulsified with an equal volume of FIA; or (8) PBS alone. Following injection, each fish was marked with a subcutaneous fluorescent latex tag denoting its treatment group and the vaccinated fish were combined into sham and disease challenge tanks. Two weeks after these fish were vaccinated, separate groups of fish were injected with either PBS or live $R$. salmoninarum GL64 and were placed inside coated-wire mesh cylinders (liveboxes) in the sham and disease challenge tanks, respectively. Mortalities in both tanks were recorded for $285 \mathrm{~d}$. Any mortalities among the livebox fish were replaced with an appropriate cohort (infected with $R$. salmoninarum or healthy) fish. None of the bacterins evaluated in this study induced protective immunity against the $R$. salmoninarum shed from the infected livebox fish. The percentage survival within the test groups in the $R$. salmoninarum challenge tank ranged from $59 \%$ (heated Rs MT239 bacterin) to $81 \%$ (PBS emulsified with FIA). There were no differences in the percentage survival among the PBS-, PBS/FIA-, r-p57and Renogen-injected groups. There also were no differences in survival among the bacterin groups, regardless of whether the bacterial cells had been heated or left untreated prior to injection.
\end{abstract}

KEY WORDS: Renibacterium salmoninarum · Bacterial kidney disease · Vaccine efficacy $\cdot$ Cohabitation challenge

Resale or republication not permitted without written consent of the publisher

\section{INTRODUCTION}

Renibacterium salmoninarum, the etiologic agent of bacterial kidney disease (BKD), is one of the most important bacterial pathogens of salmonids, accounting for as much as $80 \%$ of the mortality in cultured Pacific salmonids, Oncorhynchus spp. (Evenden et al. 1993). Efforts to control the spread of this organism have included brood stock segregation (Pascho et al.
1991) to interrupt the vertical transmission of $R$. salmoninarum, and the use of the chemotherapeutants, particularly erythromycin, to reduce or eliminate infection (Elliott et al. 1989). However, outbreaks of BKD persist despite these practices. When avoidance or treatment are impossible, vaccination may represent the most effective control method for some fish pathogens. Vaccination of fish has been done for about 60 yr and today there are commercially available- 
vaccines for several bacterial diseases of fish, including the salmonid pathogens Yersinia ruckeri, Aeromonas salmonicida, Listonella (Vibrio) anguillarum and Vibrio salmonicida (Schnick et al. 1997). However, efficacious vaccines for many other fish pathogens remain in the developmental stages.

Conventional approaches to fish vaccination do not effectively confer protection against Renibacterium salmoninarum. Salmonids respond to bacterins made from killed R. salmoninarum (Evelyn 1971, Paterson et al. 1985), but there is no clear correlation between a fish's ability to produce antibodies against $R$. salmoninarum bacterin and protection from BKD. In fact, groups of fish vaccinated with whole $R$. salmoninarum cells or isolated proteins may actually have a greater susceptibility to BKD than groups that were not vaccinated (Pascho et al. 1997). The lack of protection may be due in part to the $57 \mathrm{kDa}$ protein (p57) of $R$. salmoninarum. p57 is highly expressed in virulent $R$. salmoninarum strains as both secreted and cell-surface forms. Concentrations of secreted p57 in the serum of infected fish can be as much as $1 \mathrm{mg} \mathrm{ml}^{-1}$ (Turaga et al. 1987 ) and p57 is highly immunogenic in salmonids (Alcorn \& Pascho 2002). A high concentration of p57 in the serum of an infected fish, coupled with an elevated antibody response to the protein, may result in immune complexes, which are believed to contribute to the glomerulonephritic lesions characteristic of BKD (Kaattari \& Piganelli 1997).

Although the exact functions of the p57 protein have not been determined, it is thought to be a virulence factor of Renibacterium salmoninarum. The MT239 strain, which produces the p57 protein but lacks the cell-bound form, is less virulent than wildtype strains (Bruno 1988, Senson \& Stevenson 1999). Several of the immunosuppressive properties of $R$. salmoninarum are attributed to the p57 protein, including leucoagglutination (Wiens \& Kaattari 1991, Fredriksen et al. 1997) and reduction of the antibody response (Turaga et al. 1987, Fredriksen et al. 1997). Exposure of salmonid macrophages to p57 can reduce their bactericidal (Siegel \& Congleton 1997) and respiratory burst activity (Densmore et al. 1998). Molecules of p57 on the bacterial cell surface may also block the fish's immune response to other cell-surface antigens. Wood \& Kaattari (1996) reported that removal of p57 by heating the cells to $37^{\circ} \mathrm{C}$ for $10 \mathrm{~h}$ enhanced the immunogenicity of an $R$. salmoninarum bacterin. They reported a 20 -fold increase in the antibody response of chinook salmon injected with the modified cells compared to the response of fish injected with a bacterin made from the wildtype bacterium. The authors speculated that the increased antibody response may reflect the loss of a factor (presumably the p57 protein) that either blocks antibody synthesis, or obstructs immune reactions to other, carbohydrate antigens. The use of other, nonp57, cell surface antigens provides an intriguing vaccination strategy. The hypothesized role of p57 in immune complex formation and bacterial surfaceantigen blocking led us to examine the strategy of immunizing fish with $R$. salmoninarum cells lacking the cell-associated p57.

The long-term goal of this project is to provide fish culturists with a vaccine against Renibacterium salmoninarum. The proposed project compared the relative efficacies of 5 experimental vaccines and 1 commercial vaccine against $R$. salmoninarum to protect juvenile chinook salmon during a waterborne challenge with a wildtype $R$. salmoninarum.

\section{MATERIALS AND METHODS}

Fish. Fish for this study were reared from eggs obtained from brood year 1998 and 2000 Root River (Wisconsin, USA) fall chinook salmon Oncorhynchus tshawytscha. Chinook salmon, brood year 2000, from the Abernathy Salmon Culture Technology Center (Washington, USA) were also used in this study. The presence and levels of Renibacterium salmoninarum in the spawning parental fish were determined by testing samples of kidney tissue and ovarian fluid using either the enzyme-linked immunosorbent assay (ELISA, Pascho et al. 1991) or the membrane filtration fluorescent antibody test (MF-FAT, Elliott \& McKibben 1997). Eyed eggs from 5 mating pairs, in which both parents were categorized as negative for $R$. salmoninarum infection, were transferred to the Western Fisheries Research Center (US Geological Survey), Seattle, Washington, USA. The fish were reared in sandfiltered, UV-treated Lake Washington water at $12^{\circ} \mathrm{C}$ throughout the study. For each salmon stock and brood year, the progeny fish were combined at the fry stage and reared in $712 \mathrm{l}$ circular tanks. The fish were fed ad libitum daily with a pelleted, semi-moist commercial diet (BioOregon).

Renibacterium salmoninarum whole cell bacterins. Two strains of Renibacterium salmoninarum were used in this study: (1) ATCC strain 33209 (Rs 33209), which has cell-surface bound p57 (Wiens \& Kaattari 1989) and (2) the MT-239 strain (Rs MT239), which produces the p57 protein but does not attach it to the cell surface (Bruno 1988). Each strain was grown in KDM 2 broth at $15^{\circ} \mathrm{C}$ for about $14 \mathrm{~d}$. The bacteria were washed 3 times and resuspended in phosphate-buffered saline (PBS). One half of the volume of both strain preparations was heated to $37^{\circ} \mathrm{C}$ for $48 \mathrm{~h}$ and washed twice with PBS to remove residual p57 (Wood \& Kaattari 1996). The 4 preparations were then inactivated in $0.85 \%(\mathrm{w} / \mathrm{v})$ $\mathrm{NaCl}$ containing $0.4 \%(\mathrm{v} / \mathrm{v})$ formalin for $24 \mathrm{~h}$ at $4^{\circ} \mathrm{C}$. 
The concentration of the 4 preparations were equilibrated from the original broth cultures on the basis of total cell counts by the MF-FAT and standard quantitative microbiological methods using KDM 2 agar plates.

The successful removal of p57 from the heated Rs 33209 and Rs MT239 cellular preparations was confirmed by Western blot analysis. All labware and reagents were purchased from BioRad Laboratories unless otherwise stated. The Mini-PROTEAN II was used for sodium dodecyl sulfate-polyacrylamide gel electrophoresis (SDS-PAGE) according to the manufacturer's recommendations. The 4 inactivated bacterial preparations were diluted 1:50 with PBS. PBS solutions containing $13.5 \mu \mathrm{g} \mathrm{ml}^{-1}$ of recombinant p57 (see below) and each of the 4 bacterial preparations were separately mixed with an equal amount of SDS-PAGE sample buffer, and incubated at $95^{\circ} \mathrm{C}$ for $4 \mathrm{~min}$. Then, $20 \mu \mathrm{l}$ of each sample was separated by SDS-PAGE for $45 \mathrm{~min}$ at $200 \mathrm{~V}, 120 \mathrm{~mA}$, in a discontinuous $0.125 \mathrm{M}$ Tris, pH 6.8, $5 \%$ acrylamide stacking gel and $0.375 \mathrm{M}$ Tris, $\mathrm{pH} 8.8,12 \%$ separating gel. The separated proteins were transferred to a $0.2 \mu \mathrm{m}$ nitrocellulose membrane using the Mini Trans-blot cell according to the manufacturer's recommendations. The free binding sites on the membrane were blocked for $1 \mathrm{~h}$ with milk protein solution (Kirkegaard and Perry Laboratories). The membrane was incubated overnight at $4^{\circ} \mathrm{C}$ in a monoclonal antibody solution: 1 part culture supernatant from each of 2 mouse hybridomas that produce antibody to different epitopes of p57 (3H1 and 4D3, Wiens \& Kaattari 1991), and 2 parts $15 \mathrm{mM}$ Tris buffered saline containing $0.05 \% \mathrm{v} / \mathrm{v}$ Tween 20 (TBS + Tween 20). The membrane was washed $(3 \times 20 \mathrm{~min})$ with TBS + Tween 20. The membrane was incubated for $1 \mathrm{~h}$ at room temperature in TBS + Tween 20 containing (1:1000) horseradish peroxidase conjugated goat-anti-mouse $\operatorname{IgG}(\mathrm{H}+\mathrm{L})$. The membrane was washed as described above and exposed to the substrate-chromogen (4-chloro-1-naphthol) solution for $5 \mathrm{~min}$. Color development was halted by rinsing the membrane with water.

Commercial bacterin. The commercial bacterin, Renogen, was purchased from Aqua Health. Renogen is a live cell vaccine containing a bacterium that shares antigenic determinants with Renibacterium salmoninarum according to the manufacturer. It was prepared and administered according to the manufacturer's instructions.

Recombinant p57. The entire DNA sequence for the p57 protein of Renibacterium salmoninarum (Chien et al. 1992) was inserted into a high-expression plasmid (pET30, Novagen). For large-scale production of the recombinant p57 protein (r-p57), the pET30-p57 plasmid was transferred to Escherichia coli HMS174 (DE3) for growth in $100 \mathrm{l}$ of Terrific broth containing $25 \mu \mathrm{g}$ $\mathrm{ml}^{-1}$ kanamycin. Expression of the r-p57 was induced by the addition of $1 \mathrm{mM}$ isopropyl $\beta$-D-thiogalactopyranoside (IPTG). $4 \mathrm{~h}$ post-induction, the culture was harvested and the $420 \mathrm{~g}$ wet weight cell pellet was stored overnight at $-70^{\circ} \mathrm{C}$. To harvest the insoluble inclusion bodies, the bacterial cells were lysed by a combination of lysozyme treatment and sonication. After thawing, the cell pellet was suspended in $20 \mathrm{mM}$ Tris buffer, pH 8.0, containing $500 \mathrm{mM} \mathrm{NaCl}, 5 \mathrm{mM}$ imidazole, $1 \mathrm{mM}$ EDTA and $2 \mathrm{mg} \mathrm{ml}^{-1}$ lysozyme. The suspension was incubated for $1 \mathrm{~h}$ at room temperature; then, Triton X-100 was added to a final concentration of $0.5 \%(\mathrm{v} / \mathrm{v})$. The suspension was incubated for an additional $30 \mathrm{~min}$ and then sonicated to ensure cell lysis. The inclusion bodies and other cellular debris were concentrated by centrifugation at $10000 \times g$, after which the 'resuspend-sonicate-spin' cycle was repeated 6 times to generate washed inclusion bodies. The insoluble material was suspended in $730 \mathrm{ml}$ of $20 \mathrm{mM}$ Tris, pH 8.0, containing $500 \mathrm{mM} \mathrm{NaCl}$ and $5 \mathrm{mM}$ imidazole, and stored at $-80^{\circ} \mathrm{C}$.

To prepare the r-p57 stock solution used in this study, an aliquot of the purified inclusion bodies was solubilized in $200 \mathrm{ml}$ of Voller PBS containing $6 \mathrm{M}$ urea at a concentration of $1.99 \mathrm{mg} \mathrm{ml}^{-1}$. The protein solution was sequentially dialyzed against Voller PBS containing decreasing concentrations of urea; 4 M, 2 M, 1 M and no urea. At each urea concentration, the r-p57 was dialyzed at $4^{\circ} \mathrm{C}$ with stirring for $24 \mathrm{~h}$. The r-p57 solution was $0.2 \mu \mathrm{m}$ filtered to sterilize, and aliquots were stored at $-80^{\circ} \mathrm{C}$. Protein concentration was determined with the Bradford protein assay (BioRad) using bovine serum albumin as the standard. Serological reactivity to the monoclonal antibodies 3H1 and 4D3, which are specific to separate epitopes of the native p57 protein (Wiens \& Kaattari 1991), was determined by Western blot.

Selection of a bacterin dose. The relative immune responses of groups of brood year 1998 Root River chinook salmon to different concentrations of the wildtype bacterin (Rs 33209) were used to select a single test dose for all of the bacterins in the challenge study. Six groups of 160 chinook salmon, mean weight of $19 \mathrm{~g}$, were injected intraperitoneally (IP) with either $100 \mu \mathrm{l}$ of $50 \mu \mathrm{g}$ r-p57 emulsified with Freund's incomplete adjuvant (FIA, positive control), or $500 \mu \mathrm{l}$ of 1 of 5 concentrations of the Rs 33209 bacterin in PBS. The amounts of the bacterin injected into fish were $5 \times$ $10^{9}, 5 \times 10^{8}, 5 \times 10^{6}, 5 \times 10^{5}$ or $5 \times 10^{3}$ cells. Each group of fish was split into 2 subgroups of 80 fish each and placed in replicate 3691 tanks.

Fish from each subgroup were bled prior to immunization (prebleed), and biweekly between 3 and 13 wk after immunization. Ten fish were captured by repeated dip netting from each replicate tank of each 
injection group and overdosed with MS222. Blood samples were collected in a heparinized Natelson capillary tube after the caudal peduncle was severed. The blood was transferred to a capped tube and incubated overnight at $4^{\circ} \mathrm{C}$. After centrifugation of the blood samples at $10000 \times g$ for $10 \mathrm{~min}$ at $4^{\circ} \mathrm{C}$, the plasma samples were collected and stored at $-80^{\circ} \mathrm{C}$.

The antigen-specific antibody response of the fish in each subgroup was determined by a quantitative ELISA based on coating the microplate well surfaces with r-p57 as a capture antigen (Alcorn \& Pascho 2000). Briefly, a standard curve was constructed by relating multiple dilutions of a high titer rainbow trout antiserum to r-p57 to their resulting ELISA absorbance values. The ELISA absorbance values produced by single dilutions of the test plasma samples were then compared to the standard curve to determine the antip57 antibody concentration. Plasma samples that had anti-p57 antibody activity greater than the cutoff value were considered to be from responder fish and were used for data analysis. The cutoff value was considered to be the mean anti-p57 antibody activity of the 'prebleed' fish plus 2 standard deviations of the mean. The dose of Rs 33209 that elicited the greatest antibody response among responder fish was selected as the experimental dose for all bacterins.

Immunization of chinook salmon. Five groups of 200 Root River chinook salmon, brood year 2000 fish weighing approximately $10 \mathrm{~g}$, each received a $500 \mu \mathrm{l}$ IP injection of either PBS or one of the Renibacterium salmoninarum bacterins. The concentration of bacterial cells in each of the $R$. salmoninarum bacterins was equal and the dose was determined as described above. Two hundred chinook salmon were injected IP with $100 \mu \mathrm{l}$ of $50 \mu \mathrm{g} \mathrm{r}$-p57 emulsified with FIA. Two hundred chinook salmon were vaccinated with Renogen according to the manufacturer's recommendation (Aqua Health). Following vaccination, the fish received a subcutaneous latex tag (New West Technologies) in the anal, dorsal or caudal fin to designate the treatment group. After injection and marking, 100 fish from each vaccination group were put in each of two $1870 \mathrm{l}$ circular tanks. The fish were maintained at $12^{\circ} \mathrm{C}$ throughout the remainder of the experiment.

Cohabitation challenge. In the cohabitation challenge, vaccinated test fish were exposed to Renibacterium salmoninarum by introduction of fish that had been previously injected with the live bacterium. During the normal course of an infection, injected fish shed $R$. salmoninarum into the water, which would potentially infect the test fish. The third passage of an $R$. salmoninarum strain originally isolated from an adult chinook salmon in Lake Michigan (Rs GL64) was used as the challenge bacterium. The challenge cul- ture was grown in KDM 2 broth at $15^{\circ} \mathrm{C}$ for $10 \mathrm{~d}$, then washed 3 times by centrifugation in PBS and resuspended in PBS. The bacterial cell concentration was determined by total cell counts using the MF-FAT, and colony-forming units by bacteriological culture on KDM 2 agar plates.

For the cohabitation challenge, exposure of the vaccinated fish to waterborne Renibacterium salmoninarum was to begin as they were undergoing their maximal immune response. While determining the optimal bacterin dose, the maximum antibody response in chinook salmon occurred 9 wk after injection with $5 \times 10^{9}$ formalin-inactivated $R$. salmoninarum. In a separate study, peak modulation of several immune functions occurred 2 to 4 wk after injection of the same concentration of $R$. salmoninarum Rs 33209 bacterin (data not shown). Based on these results, the potential for a $R$. salmoninarum bacterin to provide protection during a $R$. salmoninarum challenge was expected to begin about 4 to 9 wk after vaccination, depending on what immune functions were important for protection. In a previous study, fish injected with $1.3 \times 10^{6} \mathrm{R}$. salmoninarum began to shed detectable concentrations of bacteria after about 3 wk (McKibben \& Pascho 1999). Therefore, livebox Abernathy strain chinook salmon were injected with $R$. salmoninarum 2 wk after completion of vaccination and marking of the test fish. The exposure of the test fish to the challenge bacteria was expected to begin about $5 \mathrm{wk}$ after the test fish had been vaccinated.

Groups of 100 Abernathy chinook salmon, approximate size 10 to $15 \mathrm{~g}$, were adipose fin-clipped and injected IP with either PBS or PBS containing $1 \times 10^{6}$ Rs GL64. Eighty fish (10\% of the test population size) from the Renibacterium salmoninarum-injected group were equally distributed among 5 coated-wire mesh cylinders (liveboxes) in 1 of the challenge tanks containing the test fish ( $R$. salmoninarum challenge tank). An equal number of PBS-injected fish was placed in 5 liveboxes in the other tank of test fish (sham challenge tank). The cylindrical liveboxes were approximately $25 \mathrm{~cm}$ in diameter and as deep as the water column, about $40 \mathrm{~cm}$. The remaining injected fish were placed in separate tanks as reserves. Mortalities in both tanks were recorded for $285 \mathrm{~d}$. Periodically, the anterior kidneys of dead fish were cultured to test for $R$. salmoninarum infection. Any mortalities among the livebox fish were replaced by cohort fish from the respective reserve tank.

Survival statistics were calculated by Kaplan-Meier analysis. Differences between the percentage survival of fish in each of the treatment groups were determined by the logrank comparison. Statistical significance was set at $\mathrm{p} \leq 0.05$. 


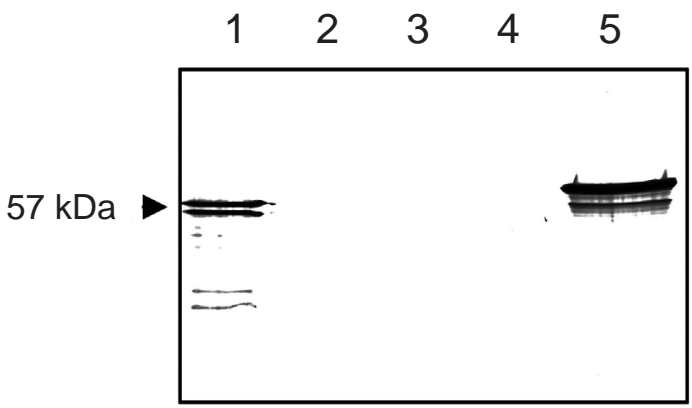

Fig. 1. Western blot analysis of the Renibacterium salmoninarum cellular preparations of strains ATCC 33209 (Rs 33209) and MT239 (Rs MT239) before, and after, heating at $37^{\circ} \mathrm{C}$ for $48 \mathrm{~h}$. The recombinant p57 protein was included. Separated proteins were reacted with 2 mouse monoclonal antibodies (3H1 and 4D3) that recognize different epitopes of the p57 protein. Lanes: (1) Rs 33209, (2) heated Rs 33209, (3) Rs MT239, (4) heated Rs MT239, (5) recombinant p57 protein

\section{RESULTS}

\section{Production of bacterins}

Heating Renibacterium salmoninarum cells to $37^{\circ} \mathrm{C}$ for $48 \mathrm{~h}$ removed $\mathrm{p} 57$ from the Rs 33209 preparation (Fig. 1). The absence of p57 bands in the lane loaded with unheated $R$. salmoninarum MT239 was expected. Whereas this strain produces the p57 protein, it lacks p57 on the cell surface (Bruno 1990, Daly \& Stevenson 1990). Thus, only very small amounts of the protein within the bacterial cells would remain for the analysis after the wash steps.

The recombinant p57 purified from lysed Escherichia coli cells was recognized by at least 1 of the monoclonal antibodies 3H1 and 4D3 (Fig. 1). The principle band in the r-p57 sample is slightly heavier than $57 \mathrm{kDa}$ because of a histidine-tag on the recombinant protein.

\section{Selection of a bacterin dose}

Among the groups of chinook salmon injected with the Rs 33209 bacterin, only the fish injected with the $5 \times$ $10^{9}$ Renibacterium salmoninarum cells produced an antibody response similar to that of the fish injected with the r-p57 (Fig. 2). The peak antibody response of fish injected with $5 \times 10^{9} R$. salmoninarum cells or r-p57 occurred about $9 \mathrm{wk}$ after injection and the magnitudes of the responses were similar. A detectable antibody response was also observed among the fish injected with $5 \times 10^{8} R$. salmoninarum cells. However, the magnitude of the antibody response to this lower concentration was lower and the peak response occurred about $7 \mathrm{wk}$ after injection. Injection of most fish with less than $5 \times$ $10^{8}$ bacterin cells failed to elicit measurable antibody.

\section{Cohabitation challenge}

On the basis of testing water samples by the MFFAT, high concentrations of Renibacterium salmoninarum were present in the water of the challenge tank $38 \mathrm{~d}$ after introduction of the infected fish (Fig. 3). The experiment was terminated $285 \mathrm{~d}$ after the introduction of the livebox fish.

At the termination of the experiment, there had been a total of 258 mortalities in the liveboxes: 15 among the sham injected fish and 243 among the Renibacterium salmoninarum-injected fish. Kidney tissue samples from all of the sham-injected livebox fish and some of the $R$. salmoninarum-injected livebox fish were

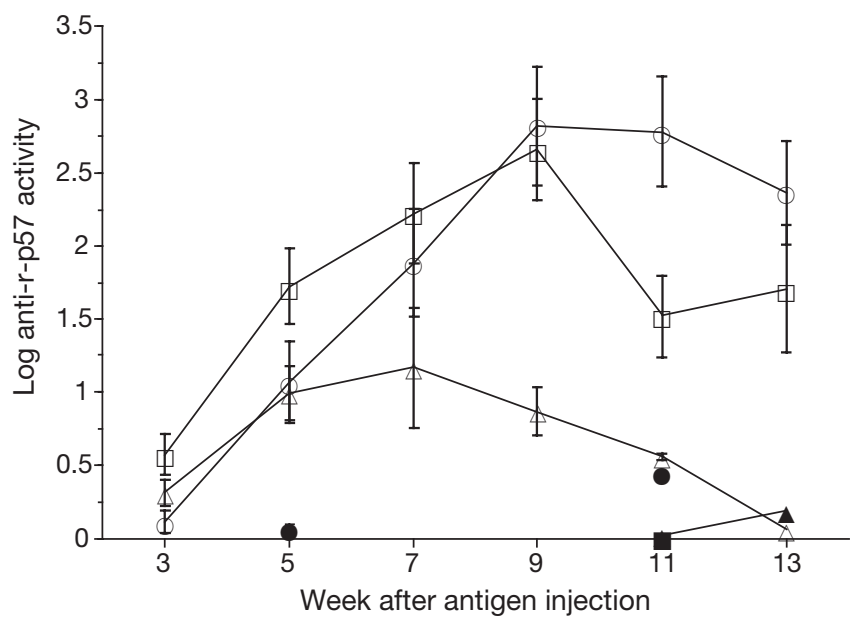

Fig. 2. Mean $( \pm \mathrm{SE}, \mathrm{n}=10)$ antibody response of chinook salmon injected with r-p57 (O), or $5 \times 10^{9}(\square), 5 \times 10^{8}(\Delta), 5 \times$ $10^{6}(\bullet), 5 \times 10^{5}(\boldsymbol{\square})$, or $5 \times 10^{3}(\mathbf{\Delta})$ untreated Rs 33209 cells

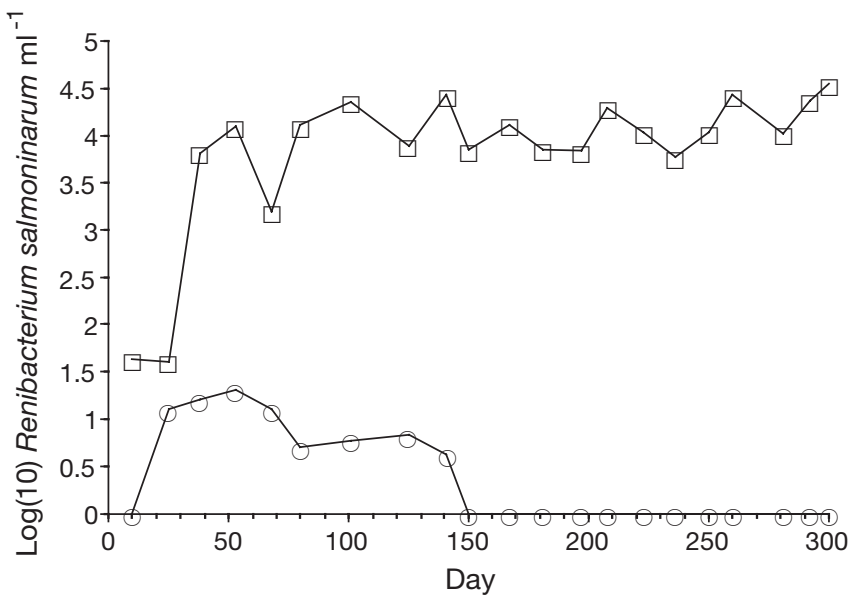

Fig. 3. Concentration of Renibacterium salmoninarum in the rearing water of the sham $(0)$ and $R$. salmoninarum ( $\square$ ) challenge tanks after the introduction of livebox chinook salmon injected with either PBS or R. salmoninarum, respectively 


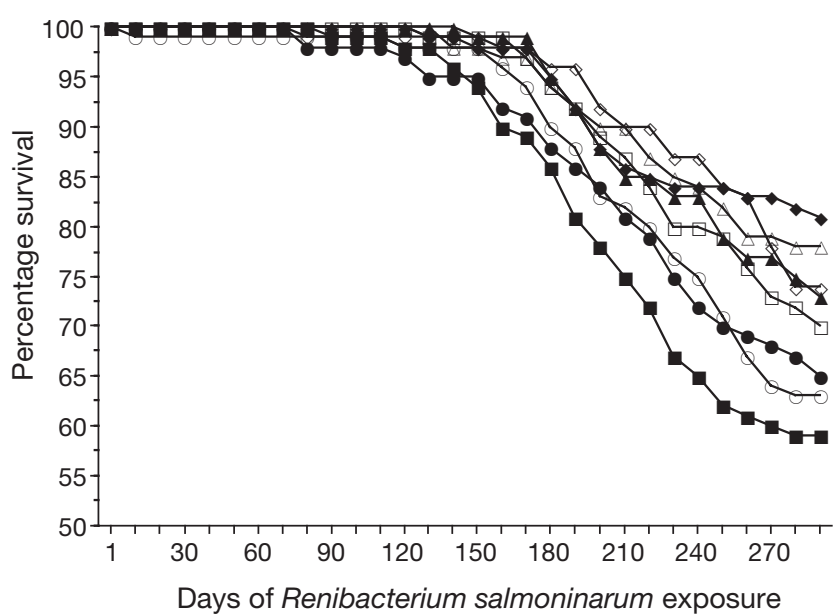

Fig. 4. Survival of experimental groups of chinook salmon during cohabitation with fish injected with Renibacterium salmoninarum. Injected fish were introduced into the challenge tank on Day 1. Data at 10 d intervals are shown for clarity. The experimental fish were injected with one of the following: Rs 33209 bacterin (O), heated Rs 33209 bacterin (•), Rs MT239 bacterin ( $\square$ ), heated Rs MT239 bacterin (घ), r-p57 emulsified with Freund's incomplete adjuvant (FIA) $(\Delta)$,

Renogen $(\boldsymbol{\Delta})$, PBS $(\diamond)$ or PBS emulsified with FIA $(\diamond)$

screened for $R$. salmoninarum infection by the fluorescent antibody test (FAT). Two of the sham-injected fish were FAT positive but in each case, only $1 R$. salmoninarum cell was observed in 50 microscope fields. In contrast, high concentrations of $R$. salmoninarum cells were observed in kidney smears from the R. salmoninarum-injected fish.

Among the test fish in the sham challenge tank, there were a total of 5 mortalities over the duration of the experiment; 1 fish each in the heat-treated Rs 33209 and Rs MT239 bacterin groups, as well as the PBS/FIA-injected treatment group, and 2 fish in the r-p57 group.

The percentage survival within the test groups in the Renibacterium salmoninarum challenge tank ranged from 59 to $81 \%$ (Fig. 4). The mean day-to-death ranged from 241 to $269 \mathrm{~d}$ (Table 1). There were no differences in the percentage survival among the PBS-, PBS/FIA-, r-p57- and Renogen-injected groups (Table 2). There also were no differences in survival among the bacterin groups, regardless of whether the bacterial cells had been heated or left untreated prior to injection. The survival among fish in the heated Rs MT239 group was less than that of the PBS-, PBS/FIA-, r-p57- and Renogen-injected groups. Survival in both the Rs 33209 and heated Rs 33209 groups was less than in the r-p57 and PBS/FIA groups.

\section{DISCUSSION}

We believe that the cohabitation Renibacterium salmoninarum challenge used in this study provided a 'real world' test of the candidate vaccines. Cohabitation challenges are unlike challenges that rely on injection or immersion with the bacterium. When bacteria are injected into the host, they circumvent a number of a fish's natural barriers to infection, including the mucus and the skin. Although immersion challenges do not allow bacteria to bypass these natural barriers, the fish are typically exposed to unnaturally

Table 1. Mortality among groups of chinook salmon vaccinated with various control or Renibacterium salmoninarum preparations followed by a cohabitation challenge

\begin{tabular}{|lcc|}
\hline Treatment group & $\begin{array}{c}\text { Mean } \\
\text { day-to-death }\end{array}$ & $\begin{array}{c}\text { Percentage } \\
\text { mortality }\end{array}$ \\
\hline Rs 33209 & 248 & 37 \\
Heated Rs 33209 & 256 & 35 \\
Rs MT239 & 266 & 30 \\
Heated Rs MT239 & 241 & 41 \\
Recombinant p57 & 264 & 22 \\
Commercial vaccine & 268 & 27 \\
PBS & 264 & 26 \\
PBS/FIA & 269 & 19 \\
\hline
\end{tabular}

Table 2. Results of paired logrank analysis of percentage survival among groups of chinook salmon injected with various control or Renibacterium salmoninarum preparations followed by cohabitation with $R$. salmoninarum-injected fish

\begin{tabular}{|lcccccc|}
\hline & Rs 33209 & Rs 33209 HT & Rs MT239 & Rs MT239 HT & rp57/FIA & Renogen \\
\hline Rs 33209 HT & 0.8418 & & & & & \\
Rs MT239 & 0.2568 & 0.3735 & & & & \\
Rs MT239 HT & 0.4188 & 0.3384 & 0.0601 & & & \\
r-p57/FIA & 0.0223 & 0.0383 & 0.2257 & 0.0027 & & \\
Renogen & 0.1197 & 0.1879 & 0.6638 & 0.0219 & 0.6400 & 0.2159 \\
PBS/FIA & 0.0065 & 0.0128 & 0.0949 & 0.0007 & 0.6400 & 0.7943 \\
PBS & 0.0627 & 0.1126 & 0.4763 & 0.0100 & 0.5990 & 0.3062 \\
\hline
\end{tabular}


high concentrations of the pathogen to ensure infection. In both injection and immersion challenges, the fish are also subjected to the additional stress of handling. Furthermore, to obtain the needed numbers of bacteria for an injection or immersion challenge the bacteria are grown in vitro, which in some cases can cause attenuation of some bacterial pathogens. The cohabitation challenge not only eliminates the technical difficulties of injection and immersion challenges, but also best approximates the natural interaction of an uncompromised host and a virulent pathogen. A vaccine that provides a slight immunological advantage to the host should have a measurable effect in a challenge that does not force the fish to suddenly interact with unnaturally high numbers of bacteria.

The results of this study highlight one of the difficulties of a cohabitation challenge, where the amount of time required to establish lethal levels of Renibacterium salmoninarum in the test fish can be significantly longer than by injection or immersion challenges (Sanders et al. 1978, Beacham \& Evelyn 1992, Murray et al. 1992). The amount of time between the introduction of the infected fish and the onset of mortality among the test fish in the $R$. salmoninarum challenge tank was expected to be about 2 mo. The mortality rates were expected to increase in such a manner that about 4 mo after introduction of the livebox fish the experiment could be terminated with mortality among the PBS-vaccinated fish exceeding $50 \%$. Although the deaths among the test fish did begin about 2 mo after introduction of the livebox fish, the mortality did not increase as expected and we did not attain $50 \%$ mortality in any of the groups. Unfortunately, we could only monitor the fish for $285 \mathrm{~d}$ due to constraints of wet-laboratory space and scheduling of other experiments.

The concentration of Renibacterium salmoninarum in the rearing water was determined using the MFFAT (McKibben \& Pascho 1999) that does not differentiate live from dead cells. $R$. salmoninarum cells were detected in water samples from both the sham and challenge tanks after introduction of the livebox fish, but probably for different reasons. In the R. salmoninarum challenge tank, the bacterial load reached about 10000 cells ml $\mathrm{ml}^{-1}$ on Day 38 and remained steady for the duration of the experiment. These cells probably represented live bacteria shed both from the $R$. salmoninarum-injected fish placed in the live boxes and (later) from infected test fish. The cells detected in the sham tank water samples may have been formalininactivated cells that were shed from the test fish vaccinated with whole cell $R$. salmoninarum bacterins. After $150 \mathrm{~d}$, the bacteria were no longer detected in water from the sham tank, suggesting that the fish had stopped shedding the bacterin cells and that there were no active $R$. salmoninarum infections. Although it seems unlikely, because of the high survival rate in the sham challenge tank, the $R$. salmoninarum cells detected in that tank may have been live bacteria shed into the water from a low number of infected fish. However, the concentration of bacteria was not great enough to perpetuate an epizootic in the sham challenge tank and bacteria were no longer detected $150 \mathrm{~d}$ after introduction of the livebox fish. If bacterin cells were also shed from the vaccinated test fish in the $R$. salmoninarum challenge tank, they probably made up only about $0.1 \%$ of the total number of cells counted. These results indicated that the livebox fish in the $R$. salmoninarum challenge tank were shedding $R$. salmoninarum at concentrations great enough to infect healthy fish residing in the same water system (Elliott \& Pascho 1995).

In this study, we examined the efficacy of 5 potential Renibacterium salmoninarum vaccines that differed relative to the amount of $\mathrm{p} 57$. The recombinant form of p57 allowed use of a virtually pure form of the protein that is known to elicit a strong antibody response in several salmonid species (Alcorn et al. 2002, Alcorn \& Pascho 2002). Both the Rs 33209 and Rs MT239 genomes contain 2 copies of the p57 gene (O'Farrell \& Strom 1999), and the p57 protein is produced by both strains. However, the protein does not associate with the Rs MT239 cell surface (Bruno 1990, Senson \& Stevenson 1999), so only p57 proteins within the Rs MT239 cells would be present in the untreated vaccine. Complete removal of internal and cell surface p57 from Rs 33209, and internal p57 from Rs MT239, was done according to established methods (Piganelli et al. 1999a) and should have exposed antigens normally masked by the p57 (Wood \& Kaattari 1996). The $R$. salmoninarum vaccines used in this study, therefore, provided a range of p57 exposure to the chinook salmon immune system.

Unfortunately, none of the vaccines tested in the current study conferred protection to the chinook salmon during an Renibacterium salmoninarum cohabitation challenge. Based on our understanding of the disease process during an $R$. salmoninarum infection (Kaattari \& Piganelli 1997), increased mortalities were expected among the fish injected with r-p57. The amount of r-p57 protein injected into the fish typically induces a measurable antibody response (Alcorn \& Pascho 2002, Alcorn et al. 2002). If a strong antibody response to the r-p57 occurs, then the subsequent exposure of the fish to p57 from an $R$. salmoninarum infection would be expected to increase the glomerulonephritis associated with BKD. The lack of increased mortalities among the r-p57-injected fish may indicate that an antibody response was not induced, or that the antibodies did not recognize the native p57 protein. However, based 
on our previous antibody response studies (Alcorn \& Pascho 2002, Alcorn et al. 2002), we believe that the amount of r-p57 injected did induce an antibody response. Also, during studies conducted to determine the bacterin dose, it was observed that $50 \mu \mathrm{g}$ of r-p57 induced a strong antibody response (Fig. 2). The monoclonal antibodes, 3H1 and 4D3, recognized r-p57 (Fig. 1) and fish exposed to the native p57 protein produced antibodies that recognized the r-p57 in an ELISA (Fig. 2). These results indicate a similar structure of recombinant and native p57. Therefore, the biological implications of injecting fish with the r-p57 remain unclear, because the protein neither provided protection nor exacerbated mortality under the conditions of the current study.

Whereas native p57 is considered to be an immunodominant protein of Renibacterium salmoninarum (Bartholomew et al. 1991), its suitability as a vaccine remains questionable. We reported previously that both chinook salmon and rainbow trout will produce a measurable antibody response to the native p57 (Alcorn \& Pascho 2002). In the current study, however, any antibody response may have been inadequate, as the r-p57 and p57(+) whole-cell $R$. salmoninarum bacterins failed to elicit protective immunity. Recently, Rhodes et al. (2004) tested the efficacy of both live and formalin-inactivated Rs MT239 vaccines for postsmoltification chinook salmon by challenging the fish by IP injection of live Rs 33209. The limited protection that Rhodes et al. (2004) described is in contrast to the results of the current study. The differences in protection may have been due to a number of factors including the stock of fish and their life stage. Also, Rhodes et al. (2004) used a bivalent Vibrio vaccine prior to seawater transfer, a prime-boost vaccination strategy for the MT239 preparations, an IP injection of $R$. salmoninarum for the challenge, and a chinook salmon population which was already infected with $R$. salmoninarum.

It has been speculated that removal of the Renibacterium salmoninaum-associated p57 might expose other, more protective antigens on the cell surface (Wood \& Kaattari 1996). Piganelli et al. (1999b) reported that vaccination of coho salmon Oncorhynchus kisutch with the $R$. salmoninarum cells that were heattreated in a manner similar to that used in the current study (Piganelli et al. 1999a) increased their survival when compared to unvaccinated fish. Conversely, the heat-treated (p57-removed) Rs MT239 cells actually exacerbated mortality in the current study, as evidenced by a comparatively earlier onset of mortality among fish in that group, and consequently, a shorter mean-day-to-death compared to the other groups. Our contrasting results with the p57-removed bacterins may simply demonstrate how slight differences in the manner in which fish are vaccinated and challenged can affect the outcome of a vaccine trial. Both the route of immunization (Kaattari \& Piganelli 1996) and the inclusion of an adjuvant in the delivery of a vaccine (Anderson 1992) can affect the antibody response and disease resistance of fish. Piganelli et al. (1999b) used injection and immersion $R$. salmoninarum challenges to measure the efficacy of the p57-removed R. salmoninarum vaccine delivered as either an intraperitoneal and intramuscular injected vaccine emulsified in the adjuvant FIA, or as an oral vaccine. In contrast, we suspended the $R$. salmoninarum bacterins in PBS for injection and then used a longer, more natural, cohabitation challenge.

The observed efficacy of a Renibacterium salmoninarum vaccine also may be affected by the relationship between the fish's immune response to the vaccine and the subsequent response to the challenge bacteria. For example, the results shown in Fig. 2 suggested that the humoral response to an $R$. salmoninarum bacterin was concentration-dependent and may not reach its peak for about 9 wk after injection. Since Piganelli et al. (1999b) used an injection challenge, the fish did not have time to develop an antibody response to the p57 before they died. The non-p57 antibodies that they produced against the p57-removed bacterin did provide some protection. In contrast, when the fish were challenged by cohabitation in our study, the fish had a greater length of time before the infection overwhelmed them. During that time, they could produce an antibody response to the p57 in addition to a secondary response to any available non-p57 antigens. Thus, increased amounts of antigen-antibody complexes would more quickly cause the development of BKD kidney lesions leading to earlier mortality. If this hypothesized scenario is correct, the use of bacterins based on p57-removed $R$. salmoninarum cells may be ineffective because fish reared in a hatchery environment may be responding to $R$. salmoninarum as a consequence of their exposure to bacteria shed from infected cohorts.

We also tested a commercial live-cell vaccine of Arthrobacter sp. nov., a species which shares common antigenic determinants to Renibacterium salmoninarum according to the manufacturer. For optimal protection, the fish needed to be at least $10 \mathrm{~g}$ at the time of immunization. A protective immune response would then develop over the course of 400 degree-days (days after immunization $\times$ water temperature $\left.\left[{ }^{\circ} \mathrm{C}\right]\right)$. The average weight of the fish was $9.1 \mathrm{~g} 52 \mathrm{~d}$ prior to the time of immunization (to reduce stress, the fish weights were not determined after they had reached a target weight of $9 \mathrm{~g}$ at a normal growth rate). Since the water temperature remained at $12^{\circ} \mathrm{C}$ throughout our study, a protective immune response should have developed at 
about $33 \mathrm{~d}$. The concentration of $R$. salmoninarum in the challenge tank water increased significantly between 25 and $38 \mathrm{~d}$ after addition of the livebox fish, or 39 to $52 \mathrm{~d}$ post immunization (Fig. 3). The commercial vaccine did not produce a protective immune response in chinook salmon in this cohabitation challenge. Renogen has been reported by the manufacturer to be protective for Atlantic salmon injected intraperitoneally with $R$. salmoninarum. The differences in the results may be due to the host species, the challenge method or other hereunto unexplained parameters. Limited protection to BKD of chinook salmon vaccinated with Renogen after smoltification has also been described (Rhodes et al. 2004). The differences in Renogen efficacy between the current study and that of Rhodes et al. (2004) may have been due to the variations in the studies described previously.

In summary, this work suggests that chinook salmon were not protected from BKD when injected with any of the vaccines against Renibacterium salmoninarum. Due to the ability of $R$. salmoninarum to survive and even replicate within host macrophages (Bandin et al. 1993, Gutenberger et al. 1997), and the detrimental consequences of inducing an antibody response, future research should focus on stimulation of the cellular immune response. Activated cytotoxic T lymphocytes (Nakanishi et al. 2002) and nonspecific cytotoxic cells could kill host cells harboring the bacteria and also secrete interleukins to activate macrophage cells (Graham \& Secombes 1988, Neumann et al. 1995). Activated fish macrophages have been shown to have increased ability to kill $R$. salmoninarum (Hardie et al. 1996) and should also stimulate the cytotoxic cells.

Acknowledgements. This project was supported by the Great Lakes Fishery Trust, project number 1999.13 and the Washington Department of Fish and Wildlife, project number 011004 N. The authors thank S. Marcquenski of the Wisconsin Department of Natural Resources and R. Nelson for their technical assistance, and Dr. J. Winton for review of the manuscript.

\section{LITERATURE CITED}

Alcorn SW, Pascho RJ (2000) Single-dilution enzyme-linked immunosorbent assay for quantification of antigen-specific salmonid antibody. J Vet Diagn Invest 12:245-252

Alcorn SW, Pascho RJ (2002) Antibody responses by chinook salmon (Oncorhynchus tshawytscha) and rainbow trout (Oncorhynchus mykiss) to various protein antigens. Fish Shellfish Immunol 13:327-333

Alcorn SW, Murray AL, Pascho RJ (2002) Effects of rearing temperature on immune functions in sockeye salmon (Oncorhynchus nerka). Fish Shellfish Immunol 12:303-334

Anderson DP (1992) Immunostimulants, adjuvants, and vaccine carriers in fish: Applications to aquaculture. Annu Rev Fish Dis 2:1-27

Bandin I, Ellis AE, Barja JL, Secombes CJ (1993) Interaction between rainbow trout macrophages and Renibacterium salmoninarum in vitro. Fish Shellfish Immunol 3:25-33

Bartholomew JL, Arkoosh MR, Rohovec JS (1991) Demonstration of the specificity of the salmonid humoral response to Renibacterium salmoninarum with a monoclonal antibody against salmonid immunoglobulin. J Aquat Anim Health 3:254-259

Beacham TD, Evelyn TPT (1992) Population and genetic variation in resistance of chinook salmon to vibriosis, furunculosis, and bacterial kidney disease. J Aquat Anim Health 4:153-167

Bruno DW (1988) The relationship between auto-agglutination, cell surface hydrophobicity and virulence of the fish pathogen Renibacterium salmoninarum. FEMS Microbiol Lett 51:135-140

Bruno DW (1990) Presence of a saline extractable protein associated with virulent strains of the fish pathogen, Renibacterium salmoninarum. Bull Eur Assoc Fish Pathol 10: $8-10$

Chien MS, Gilbert TL, Huang C, Landolt ML, O'Hara PJ, Winton JR (1992) Molecular cloning and sequence analysis of the gene coding for the $57-\mathrm{kDa}$ major soluble antigen of the salmonid fish pathogen Renibacterium salmoninarum. FEMS Microbiol Lett 96:259-266

Daly JG, Stevenson RMW (1990) Characterization of the Renibacterium salmoninarum haemagglutinin. J. Gen. Microbiol. 136:949-953.

Densmore CL, Smith SA, Holladay SD (1998) In vitro effects of the extracellular protein of Renibacterium salmoninarum on phagocyte function in brook trout (Salvelinus fontinalis). Vet Immunol Immunopathol 62:349-357

Elliott DG, McKibben CL (1997) Comparison of two fluorescent antibody techniques (FATs) for detection and quantification of Renibacterium salmoninarum in coelomic fluid of spawning chinook salmon Oncorhynchus tshawytscha. Dis Aquat Org 30:37-43

Elliott DG, Pascho RJ (1995) Juvenile fish transportation: impact of bacterial kidney disease on survival of spring/summer chinook salmon stocks. Annual report 1993 (Contract E86920048). US Fish and Wildlife Service, Seattle, WA

Elliott DG, Pascho RJ, Bullock GL (1989) Developments in the control of bacterial kidney disease of salmonid fishes. Dis Aquat Org 6:201-215

Evelyn TPT (1971) The agglutination response in sockeye salmon vaccinated intraperitoneally with a heat-killed preparation of the bacterium responsible for salmonid kidney disease. J Wildl Dis 7:328-335

Evenden AJ, Grayson TH, Gilpin ML, Munn CB (1993) Renibacterium salmoninarum and bacterial kidney disease The unfinished jigsaw. Annu Rev Fish Dis 3:87-104

Fredriksen Å, Endresen C, Wergeland HI (1997) Immunosuppressive effect of a low molecular weight surface protein from Renibacterium salmoninarum on lymphocytes from Atlantic salmon (Salmo salar L.). Fish Shellfish Immunol 7: 273-282

Graham S, Secombes CJ (1988) The production of a macrophage-activating factor from rainbow trout Salmo gairdneri leucocytes. Immunology 65:293-297

Gutenberger SK, Duimstra JR, Rohovec JS, Fryer JL (1997) Intracellular survival of Renibacterium salmoninarum in trout mononuclear phagocytes. Dis Aquat Org 28:93-106

Hardie LJ, Ellis AE, Secombes CJ (1996) In vitro activation of rainbow trout macrophages stimulates inhibition of Renibacterium salmoninarum growth concomitant with augmented generation of respiratory burst products. Dis Aquat Org 25:175-183 
Kaattari SL, Piganelli JD (1996) The specific immune system: Humoral defense. In: Iwama G, Nakanishi T (eds) The fish immune system: Organism, pathogen, and environment. Academic Press, San Diego, CA, p 207-254

Kaattari SL, Piganelli JD (1997) Immunization with bacterial antigens: bacterial kidney disease. In: Gudding R, Lillehaug A, Midtlyng PJ, Brown F (eds) Fish vaccinology, Dev Biol Stand, Vol 90. Karger, Basel, p 145-152

McKibben CL, Pascho RJ (1999) Shedding of Renibacterium salmoninarum by infected chinook salmon Oncorhynchus tschawytscha. Dis Aquat Org 38:75-79

Murray CB, Evelyn TPT, Beacham TD, Barner LW, Ketcheson JE, Prosperi-Porta L (1992) Experimental induction of bacterial kidney disease in chinook salmon by immersion and cohabitation challenges. Dis Aquat Org 12:91-96

Nakanishi T, Fischer U, Dijkstra JM, Hasegawa S, Somamoto T, Okamoto N, Ototake M (2002) Cytotoxic T cell function in fish. Dev Comp Immunol 26:131-139

Neumann NF, Fagan D, Belosevic M (1995) Macrophage activating factor(s) secreted by mitogen stimulated goldfish kidney leukocytes synergize with bacterial lipopolysaccharide to induce nitric oxide production in teleost macrophages. Dev Comp Immunol 19:473-482

O'Farrell CL, Strom MS (1999) Differential expression of the virulence-associated protein p57 and characterization of its duplicated gene msa in virulent and attenuated strains of Renibacterium salmoninarum. Dis Aquat Org 38: 115-123

Pascho RJ, Elliott DG, Streufert JM (1991) Brood stock segregation of spring chinook salmon Oncorhynchus tshawytscha by use of the enzyme-linked immunosorbent assay (ELISA) and the fluorescent antibody technique (FAT) affects the prevalence and levels of Renibacterium salmoninarum infection in progeny. Dis Aquat Org 12:25-40

Pascho RJ, Goodrich TD, McKibben CL (1997) Evaluation by enzyme-linked immunosorbent assay (ELISA) of Renibacterium salmoninarum bacterins affected by persistence of bacterial antigens. J Aquat Anim Health 9:99-107

Paterson WD, Lall SP, Airdrie D, Greer P, Greenham G, Poy M (1985) Prevention of disease in salmonids by vaccination and dietary modification. Fish Pathol 20:427-434

Piganelli JD, Wiens GD, Kaattari SL (1999a) Elevated temper-

Editorial responsibility: David Bruno,

Aberdeen, UK ature treatment as a novel method for decreasing p57 on the cell surface of Renibacterium salmoninarum. Dis Aquat Org 36:29-35

Piganelli JD, Wiens GD, Zhang JA, Christensen JM, Kaattari

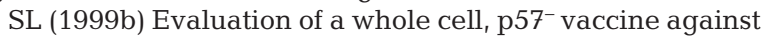
Renibacterium salmoninarum. Dis Aquat Org 36:37-44

Rhodes LD, Rathbone CK, Corbett SC, Harrell LW, Strom MS (2004) Efficacy of cellular vaccines and genetic adjuvants against bacterial kidney disease in chinook salmon (Oncorhynchus tshawytscha). Fish Shellfish Immunol 16: 461-474

Sanders JE, Pilcher KS, Fryer JL (1978) Relation of water temperature to bacterial kidney disease in coho salmon (Oncorhynchus kisutch), sockeye salmon (O. nerka), and steelhead trout (Salmo gairdneri). J Fish Res Board Can 35:8-11

Schnick RA, Alderman DJ, Armstrong R, Le Gouvello R, Ishihara S, Lacierda EC, Percival S, Roth M (1997) World wide aquaculture drug and vaccine registration progress. Bull Eur Assoc Fish Pathol 17:251-260

Senson PR, Stevenson RMW (1999) Production of the $57 \mathrm{kDa}$ major surface antigen by a non-agglutinating strain of the fish pathogen Renibacterium salmoninarum. Dis Aquat Org 38:23-31

Siegel DC, Congleton JL (1997) Bactericidal activity of juvenile chinook salmon macrophages against Aeromonas salmonicida after exposure to live or heat-killed Renibacterium salmoninarum or to soluble proteins produced by R. salmoninarum. J Aquat Anim Health 9:180-189

Turaga P, Wiens G, Kaattari S (1987) Bacterial kidney disease: the potential role of soluble protein antigen(s). J Fish Biol 31 (Suppl A):191-194

Wiens GD, Kaattari SL (1989) Monoclonal antibody analysis of common surface protein(s) of Renibacterium salmoninarum. Fish Pathol 24:1-7

Wiens GD, Kaattari SL (1991) Monoclonal antibody characterization of a leukoagglutinin produced by Renibacterium salmoninarum. Infect Immun 59:631-637

Wood PA, Kaattari SL (1996) Enhanced immunogenicity of Renibacterium salmoninarum in chinook salmon after removal of the bacterial cell surface-associated $57 \mathrm{kDa}$ protein. Dis Aquat Org 25:71-79

Submitted: February 11, 2004; Accepted: July 19, 2004

Proofs received from author(s): February 3, 2005 